\title{
IgD in Human Colostrum
}

\author{
MARGARET A. KELLER, DOUGLAS C. HEINER, AILEEN S. MYERS, AND \\ DIANE M. REISINGER \\ Department of Pediatrics, UCLA School of Medicine, Harbor-UCLA Medical Center, Torrance, California 90509
}

\begin{abstract}
Simultaneous colostrum (C) and plasma samples (P) from 14 women, 1 to 5 days postpartum, were examined. Total IgD and specific IgD antibodies to $\beta$ lactoglobulin, bovine serum albumin, Bermuda grass, and $\alpha$-gliadin were measured by solid phase radioimmunoassay. The geometric mean concentrations of IgD were 35.8 (range 2.2-410) $\mu \mathrm{g} / \mathrm{dl}$ for colostrum and 591.3 (range 724100) $\mu \mathrm{g} / \mathrm{dl}$ for plasma. Six subjects had a specific IgD antibody $C / P$ ratio more than 10 -fold greater than the total IgD $C / P$ ratio, suggesting enhancement of antibody to a specific antigen in the mammary gland. All six had $C / P$ ratios suggestive of local enhancement of IgD antibody to Bermuda grass, and two met this criterion for enhancement of IgD antibodies to $\beta$-lactoglobulin, bovine serum albumin, or $\alpha$-gliadin. Specimens for these studies were obtained during the peak grass pollen season. Seventeen additional subjects were studied to compare total IgD in colostrum and plasma with total IgG and serum albumin. The mean $\mathrm{C} / \mathrm{P}$ ratio for $\mathrm{IgD}(0.055 \pm 0.015)$ exceeded the $C / P$ ratio for total IgG $(0.015 \pm 0.003)$ or total albumin $(0.020 \pm$ $0.002)$. For 14 of 17 subjects the colostrum/plasma ratio for IgD exceeded the $C / P$ ratio for albumin or IgG. Data were transformed logarithmically and correlation coefficients calculated. For albumin versus IgG in colostrum, there was a strong correlation, $r=0.865, p=0.001$. This was different from albumin versus $\operatorname{IgD}, r=0.489, p=$ 0.046 and from IgD versus IgG, $r=0.556, p=0.020$. These analyses support a different mechanism of entry of IgD into milk compared to IgG or albumin. These studies also suggest that IgD antibodies may participate in responses of the mucosal immune system. (Pediatr Res 19: 122-126, 1985)
\end{abstract}

\section{Abbreviations}

C, colostrum

$P$, plasma

$\mathbf{C} / \mathbf{P}$, colostrum/plasma ratio

BG, Bermuda grass

BLG, $\beta$-lactoglobulin

BSA, bovine serum albumin

Recent interest in both animal and human breast milk immunology concerns homing of lymphoblasts from mucosal sites to the mammary gland with resultant local production of im-

Received May 17, 1984; accepted August 29, 1984.

Correspondence address Margaret A. Keller, M.D., Harbor-UCLA Medical Center, 1000 W. Carson Street, E6 Laboratory, Torrance, CA 90509.

This work was supported in part by New Investigator Grant A1-17124-01 from National Institute of Allergy and Infectious Diseases, a Young Investigator Grant from the California Research and Medical Education Fund of the American Lung Association of California and by NIH-GCRC Grant RR00425. munoglobulin in the mammary gland $(1,11,23,26)$. Evidence has been advanced for a common mucosal immune system involving the gastrointestinal tract, respiratory tract, salivary glands, lacrimal glands, and mammary glands (12, 18, 19, 27).

Although IgA is the principal immunoglobulin in human milk and is locally produced in the mammary gland $(7,20)$, data have also supported some local production of $\operatorname{IgM}(7,20)$ and $\operatorname{IgG}_{4}$ (13). IgD levels have been examined in human milk $(2,9,24)$, and comparison of parallel milk and plasma $\mathrm{IgD}$ and $\mathrm{IgE}$ values suggest either selective transfer into colostrum or possible local production of these immunoglobulins in the mammary gland of individual subjects (2).

We wished to examine further the question of local mammary production of $\mathrm{IgD}$ and possible participation of $\mathrm{IgD}$ in a mucosal immune system. We examined paired colostrum and plasma samples for total IgD and IgD specific antibodies to $\mathrm{BG}, \alpha-$ gliadin, BLG, and BSA to look for evidence of enhancement of specific IgD antibodies in human colostrum. These antigens were chosen as representative of antigens to which mucosal surfaces are exposed.

A second series of subjects was studied for IgD, albumin, and IgG in colostrum and plasma. The purpose of this study was to determine if total IgD was enhanced in colostrum compared to albumin and IgG, proteins which appear in the milk presumably by passive transfer from the serum.

\section{MATERIALS AND METHODS}

Informed consent was obtained from 31 postpartum women to obtain colostrum and peripheral blood specimens. Paired samples were obtained 1 to 5 days postpartum. Colostrum was obtained using either a hand pump (Lopuco, West Laurel, MD) or an electric pump (Egnell, Cary, IL). Blood samples were obtained at the time of colostrum collection by venipuncture and were heparinized using 10 units of heparin per $\mathrm{ml}$.

Colostrum samples were centrifuged at $400 \times g$ for $15 \mathrm{~min}$ to remove cells and were further clarified at $12,100 \times g$ for $30 \mathrm{~min}$ after which they were frozen at $-20^{\circ} \mathrm{C}$ until assayed.

Total IgD was determined using a paper disc solid phase radioimmunoassay (15) in which cyanogen bromide-activated paper discs were coated with rabbit anti-human $\operatorname{IgD}(\mathrm{Fc})$. Human $\mathrm{IgD}(\mathrm{Fc})$ was prepared and isolated by a method similar to that used previously to prepare $\operatorname{IgE}(\mathrm{Fc})(15)$ with the following modifications. Papain digestion of $\mathrm{D}$-myeloma protein was shortened to $15 \mathrm{~min}$ in preparing $\operatorname{IgD}(\mathrm{Fc})$. Epsilon aminocaproic acid, 10 $\mathrm{mM}$, was present in all reagents used during the isolation and digestion of $\mathrm{D}$-myeloma protein and in all affinity chromatography and radioimmunoassays involving IgD. Rabbits were immunized with $\operatorname{IgD}(\mathrm{Fc})(16)$ and rabbit anti-IgD $(\mathrm{Fc})$ was purified from rabbit antisera by fractional ammonium sulphate precipitation and by immunoadsorption of anti-IgD antibody to a second insolubilized D-myeloma protein followed by elution with 6 molar urea. This isolation by affinity chromatography also served to remove anti-idiotype antibodies. 
The product, when ${ }^{125}$ I-labeled by the chloramine-T technique (16), showed $45 \%$ binding to a D-myeloma coated paper disc, indicating that at least $45 \%$ of the product was undenatured specific anti-IgD antibody. Less than $1 \%$ bound to discs coated with $\mathrm{IgG}$. Inhibition of binding of ${ }^{125} \mathrm{I}$-anti $\mathrm{IgD}$ to solid phase IgD was shown with $\mathrm{D}$ myeloma protein but not with $\mathrm{IgG}, \operatorname{IgA}$, IgM, or IgE myeloma proteins.

Anti $\mathrm{IgD}(\mathrm{Fc})$ was covalently bound to cyanogen bromide activated discs. Test samples were incubated with the discs. These assays were performed with $5 \mu \mathrm{l}$ of plasma and $200 \mu \mathrm{l}$ of $0.1 \mathrm{M}$ phosphate buffer $(20 \%$ unsuckled calf serum, $0.005 \mathrm{M}$ epsilon aminocaproic acid, $0.02 \%$ sodium azide, and $0.05 \%$ tween 20 ). For colostrum studies (subjects 1 to 14) the volume of colostrum used $(50 \mu \mathrm{l})$ was 10 times more than the volume of plasma used. The volume of buffer was decreased accordingly. In all assays, the total volume of specimen plus buffer was constant for both colostrum and plasma. This adjustment in volume was made since the total IgD content is lower in colostrum than in plasma. After washing, approximately $50,000 \mathrm{cpm}$ of ${ }^{125}$ I-labeled antiIgD (specific activity $4 \mu \mathrm{Ci} / \mu \mathrm{g}$ ) were added. Counts per minute bound to each disc after removing unbound label were proportional to the total $\mathrm{IgD}$ in the test sample. Standard curve for percent bound radioactivity was drawn from the counts bound using dilutions of a known standard serum tested in the same assay. The standard curve ranged from 0.6 to $36,000 \mu \mathrm{g} / \mathrm{dl}$. All assays were performed in duplicate and duplicate values did not deviate from the mean by more than $15 \%$. All colostrum and plasma pairs were assayed simultaneously in the same assay.

For the second series of subjects (nos. 15 to 31 ), the IgD in plasma and colostrum samples was first assayed as above. One subject (no. 26) was noted to have less than $1 \mu \mathrm{g} / \mathrm{dl} \mathrm{IgD}$ in both colostrum and plasma. This subject's IgD-deficient colostrum was then used to construct a separate IgD colostrum standard curve by adding $5 \mu \mathrm{l}$ of serial dilutions of a control serum $(36,000$ $\mu \mathrm{g} / \mathrm{dl}$ of IgD) to $150 \mu \mathrm{l}$ of buffer plus $50 \mu \mathrm{l}$ of IgD-deficient colostrum. Colostrum samples (nos. 15 to 31$)(50 \mu \mathrm{l})$ plus 150 $\mu 1$ of buffer and $5 \mu 1$ of a 1:100 dilution of serum without detectable IgD were then assayed for percentages of counts bound to the disc. IgD values were read from the colostrum curve and divided by 10 since 10 times more colostrum was added to the disc than control serum used for the standard curve. The assay was done in this way to control for differences in protein content of colostrum and plasma samples and possible effects of other colostrum constituents. The colostrum values for total IgD were lower when read from the colostrum curve compared to the plasma curve. It was not possible to reassay the first series of specimens (nos. 1 to 14) using a colostrum standard curve since the supply of IgD deficient colostrum had been exhausted.

Specific IgD. Specific IgD antibodies were measured using a solid phase radioimmunoassay technique, the basic steps for which were described previously (16), for subjects (nos. 1 to 14). Preparation of specific antigen coated discs was carried out by incubating $2 \mathrm{mg} / \mathrm{ml}$ of protein antigen with cyanogen bromide activated paper discs at $4^{\circ} \mathrm{C}$ for $72 \mathrm{~h}$. BSA was obtained from Sigma (St. Louis, MO), BG from Hollister-Stier (Spokane, WA), $\alpha$-gliadin from USDA Northern Utilization Research and Development Division (Peoria, IL), BLG from Pentex Research Products Division, Miles Laboratories, Inc., Kankakee, IL.

Either $5 \mu \mathrm{l}$ plasma or $50 \mu \mathrm{l}$ colostrum previously diluted with buffer to give a constant total volume of $100 \mu \mathrm{l}$ was incubated with an antigen coated disc. Discs were washed with $0.1 \mathrm{M}$ phosphate buffer containing $5 \%$ human serum albumin. ${ }^{125} \mathrm{I}-$ anti-IgD was then incubated with each disc and washed. The percentage of labelled anti-IgD bound to the disc was proportional to the amount of specific antibody present in the sample. All assays were performed in duplicate and duplicate values did not deviate from the mean by more than $15 \%$. All colostrum and plasma pairs were assayed simultaneously in the same assay.

Standard curves were drawn for each antigen utilizing dilutions of known strongly positive sera each of which was assigned a value of $10,000 \mathrm{AU}$. Since the volume of colostrum used was 10 times greater than the volume of plasma, the sensitivity of the colostrum assays was 10 times greater than the plasma assays. An a- $\gamma$-globulinemic serum and a pooled serum from 12 healthy adults were also tested in each assay. It was not possible to reassay specific $\mathrm{IgD}$ antibody using a colostrum standard curve since the supply of IgD-deficient colostrum had been exhausted.

Serum albumin was assayed using radial immunodiffusion plates from Kallestad (Austin, TX). Low level albumin plates were used for colostrum. All measurements were done in duplicate and the mean value recorded. Total IgG was also assayed by radial immunodiffusion. Ultra low level plates from Kallestad were used for colostrum, and standard level plates (Meloy, Springfield, VA) were used for plasma values.

\section{RESULTS}

Data for subjects (nos. 1 to 14) are summarized in Table 1. Total IgD, specific IgD antibodies, geometric means, and colostrum/plasma ratios are listed for these antibodies. Specific antibody data for pooled normal serum and an agammaglobulinemic serum are also listed. The mean values for colostrum were considerably lower than mean values for plasma with the exception of BG data. The mean colostrum/plasma ratio ( $\pm S E M)$ for total $\mathrm{IgD}$ was $0.118 \pm 0.049$ while similar colostrum/plasma ratios for specific IgD antibodies were $0.168 \pm 0.028$ for BLG, $0.499 \pm 0.124$ for $\mathrm{BG}, 0.165 \pm 0.031$ for $\mathrm{BSA}$, and $0.141 \pm$ 0.028 for $\alpha$-gliadin. For six subjects a specific IgD antibody colostrum/plasma ratio exceeded the comparison total IgD colostrum/plasma ratio by a factor greater than 10 . These data demonstrate a marked enrichment of IgD antibodies of certain specificity in the colostrum and suggest the possibility of local production.

All six subjects with evidence of local antibody production had enrichment of anti-BG antibodies in colostrum. For each of the other three IgD antibodies assayed (BLG, BSA, $\alpha$-gliadin), two subjects showed antibody enhancement. All these specimens were obtained from the end of March to the beginning of August 1978 , a period of time which coincides with the peak season for grass pollen in the Los Angeles basin. Only one of the six subjects with enhanced anti-BG IgD antibodies in colostrum had an allergic history. This subject was allergic to a medication and possibly had hay fever symptoms.

The sign test (4) was used to compare the colostrum/plasma ratios for each of the specific IgD antibodies with the colostrum/ plasma ratios for total $\mathrm{IgD}$. The colostrum/plasma ratios for Bermuda grass specific IgD were significantly higher than the $C /$ $\mathrm{P}$ ratios for $\operatorname{IgD}(p<0.01)$. The ratios for BSA, BLG, and $\alpha-$ gliadin were not significantly higher than the $\operatorname{IgD} C / \mathrm{P}$ ratios.

Data from Table 1 were transformed logarithmically and the Pearson correlation coefficient was calculated (3) for total colostrum IgD compared to specific IgD antibody in colostrum. There was no positive correlation between specific and total $\operatorname{IgD}$ in colostrum.

These data demonstrate that high specific IgD antibody in colostrum was not associated with high total IgD in colostrum and indicate that $\mathrm{IgD}$ antibodies of certain specificities are enhanced in colostrum.

In addition, the Pearson correlation coefficient was calculated comparing colostrum and plasma values for each specific IgD antibody. A positive correlation was found for BLG specific IgD in colostrum versus plasma $(\mathrm{r}=0.569, p=0.034)$ but not for $\mathrm{BG}, \alpha$-gliadin, or BSA in colostrum versus plasma. The lack of a positive correlation between colostrum and plasma values for $\mathrm{BG}, \mathrm{BSA}$, and $\alpha$-gliadin specific IgD antibodies would further support an hypothesis that these antibodies were not passively transferred from the serum.

$I g D$, albumin, and $\operatorname{Ig} G$. Further information relating to the possible local production of specific IgD antibodies in colostrum was obtained by study of additional colostrum-plasma pairs for 
Table 1. Specific IgD antibodies and total IgD in colostrum and plasma from postpartum subjects*

\begin{tabular}{|c|c|c|c|c|c|c|c|c|c|c|c|c|c|c|c|}
\hline \multirow[b]{2}{*}{ Subject } & \multicolumn{3}{|c|}{ BG } & \multicolumn{3}{|c|}{ BSA } & \multicolumn{3}{|c|}{$\alpha$-Gliadin } & \multicolumn{3}{|c|}{ BLG } & \multicolumn{3}{|c|}{ Total IgD } \\
\hline & $\mathrm{C}$ & $\mathrm{P}$ & $\mathrm{C} / \mathrm{P}$ & $\mathrm{C}$ & $\mathbf{P}$ & $\mathrm{C} / \mathrm{P}$ & $\mathrm{C}$ & $\mathbf{P}$ & $\mathrm{C} / \mathrm{P}$ & $\mathrm{C}$ & $\mathbf{P}$ & $\mathrm{C} / \mathrm{P}$ & $\mathrm{C}$ & $\mathrm{P}$ & $\mathrm{C} / \mathrm{P}$ \\
\hline PS $\dagger$ & & 200 & & & 245 & & & 500 & & & 107 & & & 780 & \\
\hline $\mathrm{A} \gamma \ddagger$ & & $<10$ & & & $<10$ & & & $<10$ & & & $<10$ & & & $<0.6$ & \\
\hline 1 & 40 & 60 & 0.67 & 11 & 215 & 0.05 & 16 & 420 & 0.04 & 8.5 & 43 & 0.20 & 410 & 1400 & 0.29 \\
\hline 2 & 24 & 275 & 0.09 & 24 & 140 & 0.17 & 38 & 420 & 0.09 & $<1.0$ & $<10$ & & 21 & 340 & 0.06 \\
\hline 3 & 53 & 72 & $0.74 \S$ & 34 & 96 & 0.35 & 28 & 205 & 0.14 & 7.2 & 55 & 0.13 & 8.4 & 220 & 0.04 \\
\hline 4 & 125 & 64 & $1.95 \S$ & 47 & 100 & $0.47 \S$ & 65 & 155 & $0.42 \S$ & 7.0 & 52 & 0.14 & 2.2 & 72 & 0.03 \\
\hline 5 & 47 & 158 & $0.30 \S$ & 18 & 190 & 0.10 & 14 & 350 & 0.04 & 4.5 & 42 & 0.12 & 100 & 4100 & 0.02 \\
\hline 6 & 4.7 & 50 & 0.09 & 12 & 105 & 0.11 & 21 & 140 & 0.15 & 3.5 & 54 & 0.07 & 92 & 140 & 0.67 \\
\hline 7 & 24 & 90 & 0.27 & 22 & 130 & 0.17 & 44 & 210 & 0.21 & 3.3 & 25 & 0.13 & 30 & 400 & 0.08 \\
\hline 8 & 20 & 100 & 0.20 & 17 & 170 & 0.10 & 31 & 450 & 0.07 & 5.8 & 21 & 0.28 & 49 & 840 & 0.06 \\
\hline 9 & 48 & 133 & 0.36 & 18 & 160 & 0.11 & 30 & 155 & 0.19 & 8.4 & 150 & 0.06 & 120 & 560 & 0.21 \\
\hline 10 & 60 & 125 & 0.48 & 22 & 120 & 0.18 & 36 & 250 & 0.14 & 5.4 & 45 & 0.12 & 58 & 730 & 0.08 \\
\hline 11 & 36 & 100 & 0.36 & 12 & 130 & 0.09 & 33 & 400 & 0.08 & 11.4 & 32 & 0.36 & 56 & 1200 & 0.09 \\
\hline 12 & 23 & 72 & $0.32 \S$ & 15 & 135 & 0.11 & 26 & 780 & 0.03 & 15.0 & 62 & $0.24 \S$ & 56 & 3200 & 0.02 \\
\hline 13 & 27 & 46 & $0.59 \S$ & 13 & 140 & 0.09 & 23 & 130 & 0.18 & 4.2 & 76 & 0.06 & 34 & 1000 & 0.03 \\
\hline 14 & 17 & 30 & $0.57 \S$ & 21 & 100 & $0.21 \S$ & 35 & 175 & $0.20 \S$ & 8.4 & 30 & $0.28 \S$ & 3.5 & 280 & 0.01 \\
\hline $\begin{array}{l}\text { Geometric } \\
\text { mean }\end{array}$ & 30.9 & 84.2 & & 18.7 & 134.0 & & 29.2 & 261.9 & & 5.7 & 41.5 & & 35.8 & 591.3 & \\
\hline
\end{tabular}

* Specific antibodies are expressed in arbitrary units (AU) and $\mathrm{IgD}$ in $\mu \mathrm{g} / \mathrm{dl}$.

$\dagger$ Pooled normal serum.

$¥$ Serum from a- $\gamma$-globulinemic patient.

$\S$ Indicates specific IgD colostrum/plasma ratio exceeded total IgD colostrum/plasma ratio by a factor $>10$.

albumin, total $\mathrm{IgD}$, and total $\mathrm{IgG}$. Albumin and $\mathrm{IgG}$ were used as comparison proteins since presumably they are leaked from the plasma to milk and are not locally produced in the mammary gland. Values are shown in Table 2 with the geometric means. The colostrum/plasma ratios for albumin, IgD, and IgG are also illustrated in Figure 1.

The arithmetic mean colostrum/plasma ratio for $\operatorname{IgD}(0.055$ $\pm 0.015)$ exceeded the mean colostrum/plasma ratio for albumin $(0.020 \pm 0.002)$ and for $\operatorname{IgG}(0.015 \pm 0.003)$. For 14 of the 17 patients, the individual colostrum/plasma ratio for IgD exceeded the colostrum/plasma ratio for albumin, and for subject 19 , the total IgD colostrum/plasma ratio was more than 10 times higher than the similar albumin ratio. The $\mathrm{C} / \mathrm{P}$ ratio for $\mathrm{IgD}$ exceeded the ratio for $\mathrm{IgG}$ for all subjects except the IgD-deficient subject. The data for IgG are strikingly different since the $\mathrm{C} / \mathrm{P}$ ratio was lower than the albumin $\mathrm{C} / \mathrm{P}$ ratio for 16 of the 17 subjects studied. The sign test (4) was used to compare the colostrum/ plasma ratios for $\operatorname{IgD}, \operatorname{IgG}$, and albumin. The $\operatorname{IgD}$ ratios were significantly higher than the $\operatorname{IgG}$ ratios $(p<0.01)$ or the albumin ratios $(p<0.01)$. In addition, the IgG ratios were significantly lower than the albumin ratios $(p<.01)$. Both $\operatorname{IgD}(\mathrm{mol}$ wt $=$ $175,000)$ and $\operatorname{IgG}(\mathrm{mol} w \mathrm{wt}=150,000)$ have a higher molecular weight than albumin $(60,000)$. One might expect more leakage from serum of the lower molecular weight albumin than either IgD or IgG. Yet IgD has the highest molecular weight and was enhanced in colostrum compared to IgG or albumin. Such data suggest enhancement of total IgD in colostrum, not a nonspecific transfer from serum.

The data in Table 2 were transformed logarithmically and correlation coefficients calculated. There was no correlation between plasma albumin and IgD or between plasma IgG and IgD. However, there was a strong correlation between albumin and IgG in colostrum $(\mathrm{r}=0.865, p=0.001)$ and weaker correlations for albumin versus $\operatorname{IgD}$ in colostrum $(\mathrm{r}=0.489, p=0.046)$ and IgG versus $\mathrm{IgD}$ in colostrum $(\mathrm{r}=0.556, p=0.020)$.

Correction for serum-derived antibody. The data for total albumin, $\operatorname{IgG}$, and $\operatorname{IgD}$ were analyzed adapting the formula proposed by Donovan et al. (8) for local production of immunoglobulin in nasal polyps. $\mathrm{X}=\mathrm{Ig}_{\mathrm{M}}-\left(\frac{\mathrm{Alb}_{\mathrm{M}}}{\mathrm{Alb}_{\mathrm{S}}} \times \mathrm{Ig}_{\mathrm{S}}\right)$. The quantity of Ig produced locally $(\mathrm{x})$ is calculated from the observed Ig in the secretion (milk) by subtracting the Ig derived from serum. The ratio of albumin in the secretion to the albumin in the serum is used as the correction factor. Since the molecular weight of albumin is lower than that of immunoglobulins, leakage from serum may be higher for the albumin. Use of albumin in the above formula may result in an overcorrection for the serum contribution of immunoglobulins. Table 3 demonstrates the differences between locally produced $\mathrm{IgD}$ and $\mathrm{IgG}$. Of 16 subjects (excluding the IgD-deficient subject), 14 showed evidence of mammary production of IgD. Only one of the 17 subjects had evidence of mammary production of $\mathrm{IgG}$.

\section{DISCUSSION}

IgA and some IgM have been shown to be locally produced in the human mammary gland when both specific antibodies and mg of total antibody per gram of protein were considered $(7,20)$. Our previous work (13) suggests possible local mammary production of specific $\mathrm{IgG}_{4}$ antibodies in colostrum of some women. In addition our data comparing total IgE and $\operatorname{IgD}(2)$ in human colostrum and plasma show that there may be enhancement of either of these immunoglobulins in the colostrum of individual subjects. In the current study we compared colostrum and plasma levels of total IgD with specific IgD antibodies to determine if evidence could be found to suggest local mammary production or selective enrichment of IgD in colostrum.

For the first series of subjects (Table 1), colostrum/plasma ratios for specific IgD antibodies to four antigens were compared to the colostrum/plasma ratio for total IgD. Such comparison serves to control for volume and protein variations of colostrum specimens. The finding of more than 10 times the expected colostrum/plasma ratio of specific IgD antibodies to either BLG, BSA, BG, or $\alpha$-gliadin in specimens from six subjects suggested local production since selective transfer of $\mathrm{IgD}$ with a particular antibody specificity from serum into colostrum would be unlikely. It is also important to note that the subjects demonstrating colostrum enhancement of IgD specific antibodies (Table 1) were not restricted to those subjects with high total IgD in colostrum.

The observations in the initial group (Table 1) showing IgD antibodies to four mucosal antigens, BG, BSA, BLG, $\alpha$-gliadin revealed a marked enhancement of BG-specific IgD antibody in 
Table 2. Colostrum and plasma values for albumin, total IgD, and total IgG

\begin{tabular}{|c|c|c|c|c|c|c|c|c|c|}
\hline \multirow[b]{2}{*}{ Subject } & \multicolumn{3}{|c|}{ Albumin (mg/dl) } & \multicolumn{3}{|c|}{ Total IgD $(\mu \mathrm{g} / \mathrm{dl})$} & \multicolumn{3}{|c|}{ Total IgG (mg/dl) } \\
\hline & $\mathrm{C}$ & $\mathrm{P}$ & $\mathrm{C} / \mathrm{P}$ & $\mathrm{C}$ & $\mathbf{P}$ & $\mathrm{C} / \mathrm{P}$ & $\mathrm{C}$ & $\mathbf{P}$ & $\mathrm{C} / \mathrm{P}$ \\
\hline 15 & 54.5 & 2850 & 0.019 & 18.0 & 560 & 0.032 & 9.1 & 700 & 0.013 \\
\hline 16 & 29.3 & 3400 & 0.009 & 14.0 & 600 & 0.023 & 1.6 & 510 & 0.003 \\
\hline 17 & 37.6 & 3260 & 0.012 & 16.0 & 230 & 0.070 & 5.7 & 1120 & 0.005 \\
\hline 18 & 66.3 & 2720 & 0.024 & 43.0 & 850 & 0.051 & 13.2 & 625 & 0.021 \\
\hline 19 & 63.0 & 2350 & 0.027 & 180.0 & 640 & 0.281 & 34.3 & 900 & 0.038 \\
\hline 20 & 88.0 & 2600 & 0.034 & 47.0 & 710 & 0.067 & 20.0 & 700 & 0.029 \\
\hline 21 & 107.4 & 2975 & 0.036 & 30.0 & 980 & 0.031 & 20.4 & 680 & 0.030 \\
\hline 22 & 30.8 & 2975 & 0.010 & 35.0 & 680 & 0.051 & 3.0 & 980 & 0.003 \\
\hline 23 & 35.5 & 2600 & 0.014 & 20.0 & 1200 & 0.017 & 3.6 & 600 & 0.006 \\
\hline 24 & 25.7 & 2950 & 0.009 & 19.0 & 1600 & 0.012 & 3.8 & 980 & 0.004 \\
\hline 25 & 94.0 & 2575 & 0.037 & 44.0 & 1000 & 0.044 & 18.9 & 540 & 0.035 \\
\hline 26 & 31.6 & 2825 & 0.011 & $<0.6$ & 15 & $<0.037$ & 3.3 & 620 & 0.005 \\
\hline 27 & 42.0 & 2450 & 0.017 & 23.0 & 640 & 0.036 & 6.3 & 730 & 0.009 \\
\hline 28 & 28.0 & 2325 & 0.012 & 16.0 & 1800 & 0.009 & 4.2 & 690 & 0.006 \\
\hline 29 & 65.5 & 2450 & 0.023 & 32.0 & 980 & 0.033 & 10.0 & 640 & 0.016 \\
\hline 30 & 53.4 & 2675 & 0.020 & 76.0 & 680 & 0.112 & 6.0 & 560 & 0.011 \\
\hline 31 & 50.0 & 2025 & 0.025 & 26.0 & 850 & 0.031 & 17.9 & 740 & 0.024 \\
\hline $\begin{array}{l}\text { Geometric } \\
\text { mean }\end{array}$ & 47.8 & 2685 & 0.018 & 24.2 & 628 & 0.039 & 7.7 & 707 & 0.011 \\
\hline
\end{tabular}

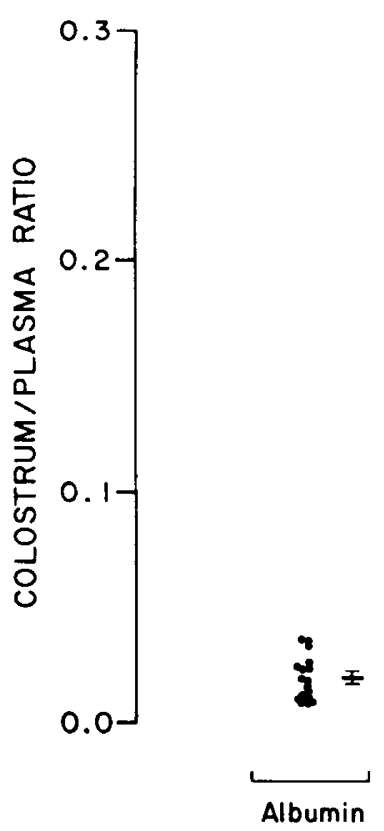

Fig. 1. The colostrum/plasma ratios for albumin, IgD, and IgG.

colostrum. At the time of this study, we had not considered that these specimens were obtained during the peak season for grass pollen allergy in our geographic locale. It was of interest that the only antigen presented to the respiratory tract mucosa stimulated the most impressive IgD antibody response. Subsequently, we have examined 18 colostrum-plasma paired specimens not obtained during the peak grass pollen season. This marked increase of $B G$ specific $\mathrm{IgD}$ antibody was not found since only one of the 18 subjects had enhanced $\mathrm{BG}$ specific $\mathrm{IgD}$ in colostrum. Thus, there is a possibility that exposure of the respiratory mucosa to a pollen antigen may result in local production of IgD antibody to that antigen in the mammary gland.

Brantztaeg et al. (6) have examined IgD production by mucosal lymphocytes and have found striking differences at different mucosal surfaces. IgD producing lymphocytes appear to be very rare in the jejunal mucosa but are present in the nasal mucosa and parotid gland. Brandtzaeg et al. (5) recently examined immunoglobulin-producing cells in biopsies of two lactating human
Table 3. Local production of immunoglobulin

\begin{tabular}{ccc}
\multicolumn{3}{c}{$I g_{\mathrm{M}}-\frac{A l b_{M}}{A l b_{P}} \times I g_{P}{ }^{*}$} \\
\hline Subjects & IgD & IgG \\
$(\mu \mathrm{g} / \mathrm{dl})$ & $(\mathrm{mg} / \mathrm{dl})$ \\
\hline 15 & 7.4 & -4.2 \\
16 & 8.6 & -3.0 \\
17 & 13.2 & -7.7 \\
18 & 22.6 & -1.8 \\
19 & 162.7 & 10.0 \\
20 & 22.9 & -3.8 \\
21 & -5.3 & -4.1 \\
22 & 28.2 & -6.8 \\
23 & 3.2 & -4.8 \\
24 & 4.6 & -5.0 \\
25 & 7.0 & -1.1 \\
26 & $\mathrm{IgD}$ deficient & -3.5 \\
27 & 12.1 & -6.1 \\
28 & -5.6 & -4.1 \\
29 & 5.5 & -7.3 \\
30 & 62.4 & -5.2 \\
31 & 4.7 & -0.6 \\
\hline
\end{tabular}

${ }^{*} \mathrm{Ig}_{\mathrm{M}}$, immunoglobulin $(\mu \mathrm{g} / \mathrm{dl}$ or $\mathrm{mg} / \mathrm{dl})$ in colostrum; $\mathrm{Alb}_{\mathrm{M}}$, albumin $(\mathrm{mg} / \mathrm{dl})$ in colostrum; Alb , albumin (mg/dl) in plasma; Igp, immunoglobulin $(\mu \mathrm{g} / \mathrm{dl}$ or $\mathrm{mg} / \mathrm{dl})$ in plasma.

mammary glands. IgD immunocytes were found in the mammary glands in proportion $(0.7$ to $2.1 \%$ ) comparable to what has been found in parotid (3.1\%) and submandibular glands (1.6\%). The percentage of $\operatorname{IgD}$ immunocytes in lacrimal glands $(9.7 \%)$ was higher. The reasons for the observed differences at different mucosal sites is not clear but these investigators concluded that an IgA-producing capacity is not a requirement for homing to glandular sites. Brantztaeg et al. (6) also found that the presence of $\mathrm{IgD}$ producing lymphocytes in nasal, lacrimal, and parotid glands was markedly amplified in IgA-deficient patients. However, since IgD was not seen in the glandular epithelial cells, Brandztaeg et al. (6) did not believe that IgD is a secretory immunoglobulin. The recent work of Plebani et al. (22) examining $\operatorname{IgD}$ in saliva and nasal secretions of children with selective IgA deficiency did not show a compensatory increase in $\operatorname{IgD}$ as 
was found for IgM. These authors failed to show a secretory role for IgD. Our current study suggests that IgD may be a participant in mucosal immunity and that respiratory tract exposure (BG) may be a particularly important determinant of the IgD composition of colostrum. Comparison of albumin colostrum/ plasma ratios and total IgD colostrum/plasma ratios provide further evidence for an enhancement of IgD in colostrum compared to albumin. IgD was also enhanced in colostrum compared to IgG. The stronger correlation between albumin and IgG in colostrum than for albumin and IgD further suggests a different mechanism for entry of IgD into milk from that of IgG or albumin. Selective transport of IgD into colostrum could explain the enhancement of total IgD but could not explain specific antibody enhancement.

When colostrum concentrations of IgD were corrected for the serum contributions adapting the formula of Donovan et al. (8) for secretory antibody production, a strong enhancement of IgD was found in colostrum. This was not the case for IgG, providing additional support for possible local mammary production of IgD.

The physiological role of $\operatorname{IgD}$ is incompletely understood at present although evidence has accumulated suggesting an immunoregulatory role for this immunoglobulin. Skelly et al. (25) have shown that mice treated from birth with a monoclonal antibody to IgD develop reduced numbers of B cells in the spleen and lymph nodes whereas splenic lymphocytes expressing sIgM are increased. Finkelman et al. (10) have demonstrated polyclonal B cell activation of the murine immune system by an antibody to IgD. Kuritani and Cooper (14) have shown the enhancing effect of anti-IgD antibody in pokeweed mitogeninduced plasma cell differentiation. All of these studies support the concept that $\operatorname{IgD}$ may act as a receptor and may regulate $B$ cell differentiation. Recent work by Xue et al. (28) demonstrated an enhanced 19S and 7S antibody response to keyhole limpet hemocyanin in mice bearing IgD-secreting plasmacytomas. The authors suggested the existence of an IgD responsive regulatory T cell.

The potential role of $\mathrm{IgD}$ as a mucosal immunoglobulin has been discussed by Olson and Leslie (21) based on their findings of an elevated IgD in rat milk. Our own studies provide support for a potential mucosal immunoglobulin role of $\mathrm{IgD}$ in humans although the mechanism regulating mammary IgD production and its function are still unknown.

Acknowledgment. The authors wish to thank Ms. Liz Neal for secretarial help.

\section{REFERENCES}

1. Allardyce RA, Shearman DJC, McClelland DBL, Marwick K, Simpson AJ, Laidlaw RB 1974 Appearance of specific colostrum antibodies after clinical infection with Salmonella typhimurium. Br Med J 3:307

2. Bahna S, Keller MA, Heiner DC $1982 \mathrm{IgE}$ and $\mathrm{IgD}$ in human colostrum and plasma. Pediatric Res 16:604

3. Beyer WH (ed) CRC Handbook of Table for Probability and Statistics, 2nd ed. The Chemical Rubber Co, Cleveland, p 389

4. Beyer WH (ed) Handbook of Tables for Probability and Statistics, 2nd ed. The
Chemical Rubber Company, Cleveland, pp 397-398

5. Brandtzaeg $P 1983$ The secretory immune system of lactating human mammary glands compared with other exocrine organs. In: McGhee JR, Mestecky J (eds) The Secretory Immune System. Annals of the New York Academy of Sciences, The New York Academy of Sciences, New York, pp 353-382

6. Brandtzaeg P, Gjeruldsen SI, Korsrud F, Baklien K, Berdal P, Ek J 1979 The human secretory immune system shows striking heterogeneity with regard to involvement of $\mathrm{J}$ chain-positive IgD immunocytes. J Immunol 122:503

7. Carlsson B, Gothefors L, Ahlstedt S, Hanson LA, Winberg J 1976 Studies of Escherichia coli antigen specific antibodies in human milk, maternal serum and cord blood. Acta Paediatr Scand 65:215

8. Donovan R, Johansson SGO, Bennich H, Soothill JF 1970 Immunoglobulins in nasal polyp fluid. Int Arch Allergy Appl Immunol 37:154

9. Dunnette SL, Gleich GJ, Miller RD, Kyle RA 1977 Measurement of IgD by a double antibody radioimmunoassay: Demonstration of an apparent trimodal distribution of IgD levels in normal human sera. J Immunol 119:1727

10. Finkelman FD, Scher I, Mond JJ, King JT, Metcalf ES 1982 Polyclonal activation of the murine immune system by an antibody to IgD. 1 . Increase in cell size and DNA synthesis. J Immunol 129:629

11. Goldblum RM, Ahlstedt S, Carlsson B, Hanson LA, Jodal U, Lidin-Janson G, Sohl-Akerluni A 1975 Antibody-forming cells in human colostrum after oral immunization. Nature 257:797

12. Jackson DE, Lally ET, Nakamura MC, Montgomery PC 1981 Migration of IgA-bearing lymphocytes into salivary glands. Cell Immunol 63:203

13. Keller MA, Heiner DC, Kidd RM, Myers AS 1983 Local production of $\mathrm{IgG}_{4}$ in human colostrum. J Immunol 130:1654

14. Kuritani T, Cooper MD 1982 Human B cell differentiation. III. Enhancing effect of monoclonal anti-immunoglobulin $\mathrm{D}$ antibody on pokeweed mitogen-induced plasma cell differentiation. J Immunol 129:2490

15. Lee SK, Metrakes JD, Tanaka KR, Heiner DC 1980 Genetic influence on serum IgD levels. Pediat Res 14:60-63

16. Lee WY, Heiner DC 1978 Preparation of rabbit anti IgE for use in radioimmunoassay of total IgE and specific IgE antibodies. J Immunol Methods $20: 185$

17. Matthews KP 1981 Calculation of secretory antibodies and immunoglobulins. J Allergy Clin Immunol 68:46

18. Mestecky J, McGhee JR, Arnold RR, Michalek SM, Prince SJ, Babb JL 1978 Selective induction of an immune response in human external secretions by ingestion of bacterial antigen. JCI 61:731

19. Mirski SE, McDermott MR, Befus AD, Bienenstock J 1981 Selective localization of mesenteric lymphoblasts in mucosal tissues: effect of altering the number of donor lymphoblasts. Immunology 43:669

20. Ogra SS, Ogra PL 1978 Immunologic aspects of human colostrum and milk: 1. Distribution characteristics and concentrations of immunoglobulins at different times after the onset of lactation. J Pediatri 92:546

21. Olson JC, Leslie GA 1982 IgD: A component of the secretory immune system? In: Thorbecke GJ, Leslie GA (eds) Immunoglobulin D: Structure and function: Annals of the New York Academy of Sciences, The New York Academy of Sciences, New York, p 97

22. Plebani A, Mira E, Mevio E, Monafo V, Notarangelo LD, Avanzini A, Ugazio AG 1983 IgM and IgD concentrations in the serum and secretions of children with selective IgA deficiency. Clin Exp Immunol 53:689

23. Roux ME, McWilliams M, Phillips-Quagliata JM, Weisz-Carrington P, Lamm ME 1977 Origin of IgA secreting plasma cells in the mammary gland. J Exp Med 146:1311

24. Sewell HF, Matthews JB, Flack V, Jefferis R 1979 Human immunoglobulin $D$ in colostrum, saliva and amniotic fluid. Clin Exp Immunol 36:183

25. Skelly RG, Baine Y, Ahmed A, Xue B, Thorbecke GJ 1983 Cell surface phenotype of lymphoid cells from normal mice and mice treated with monocional anti-IgD from birth. J Immunol 130:15

26. Weisz-Carrington P, Roux ME, Lamm ME 1977 Plasma cells and epithelial immunoglobulins in the mouse mammary gland during pregnancy and lactation. J Immunol 119:1306

27. Weisz-Carrington P, Roux ME, McWilliams M, Phillips-Quagliata JM, Lamm ME 1979 Organ and isotype distribution of plasma cells producing specific antibody after oral immunization: evidence for a generalized secretory immune system. J Immunol 123:1705

28. Xue B, Coico R, Wallace D, Siskind GW, Pernis B, Thorbecke GJ 1984 Physiology of IgD. IV. Enhancement of antibody production in mice bearing IgD-secreting plasmacytomas. J Exp Med 159:103 